\title{
Security of the Baltic States: Effectiveness of the EU Common Security and Defence Policy and Influence of the Ukrainian Crisis
}

\begin{abstract}
The paper explores the reasons behind and the development of the EU Common Security and Defence Policy (CSDP), and its advantages and disadvantages that have emerged in the process of its formation and implementation. The transformation of the CSDP according to the Lisbon Treaty and the prospects of its operation in Europe are highlighted. Special attention is paid to the issues of improving the CSDP in the context of new threats to regional and global security.

The place and role of the Baltic states in the CSDP are analysed. The position of the Baltic states in NATO, based on greater confidence in the institutions of NATO and close cooperation with the United States is considered. The basic threats and security challenges for the Baltic states nowadays are defined, including possible aggression from Russia, which is broadcast through the mainstream media as a reaction to the idea of protecting the Russian-speaking population of the Baltic states and the establishment of "geopolitical balance through their return to the Russian sphere of influence."
\end{abstract}

Key words: Common Security and Defence Policy (CSDP), the EU, European security, Baltic states, Ukraine, Russian Federation

\section{Introduction}

$\mathbf{T}$ he Russian military aggression against Ukraine has become the biggest challenge to European security since the end of the Cold War and is of great concern both to the countries of Central and Eastern Europe and the Baltic states, which could become potential targets of invasion. The reason is that Lithuania, Latvia and Estonia are an area of special geopolitical interest of the Russian Federation. In this regard, the Baltic states have begun to increase their defence capabilities using mainly the resource base of NATO. In addition to the involvement of the political and defence mechanisms of NATO, the Baltic countries are active participants in the EU Common Security and Defence Policy (CSDP), whose aim is to develop a system ensuring European security and the reduction of threats and conflicts in Europe. But can the CSDP effectively fulfil its tasks? In the case of open aggression by the Russian Federation against the Baltic states, will the EU be able to defend those countries' territorial integrity, or should the Baltic states rely only on their own forces and NATO? Taking into account the high level of unpredictability of the Russian Federation in the actions it might take (a good example of that being the Ukrainian crisis), now it is rather difficult to answer these questions.

\section{The EU Common Security and Defence Policy: the advantages and disadvanta- ges of it that have emerged in the process of its formation and implementation}

It is rather complicated to apply existing European integration theories to the EU Common Security and Defence Policy to fully explain its formation and development. 
There are many discussions among scholars concerning which theory can be better linked to the CSDP, as most of the European integration theories developed when the EU did not have even a hint of a military dimension, and they highlighted the fact that defence issues were not part of European integration (Ojanen, 2002). In such a case, it is more justified to use two of them - neo-functionalism and realism, for different stages of the development of the CSDP. The neo-functionalist idea of 'spill-over' explains the emergence of defence cooperation through the logical expansion of integration from economic and political fields to security and defence (Medley, 1999). Amitai Etzioni argued that semi-integration cannot be sustained and the EU would either have to move to a high level of supranationality in political matters, or fall back to a lower level (Etzioni, 2001). Realists explain the development of the EU defence cooperation as an attempt to balance the USA's power in world politics. For instance, Maria Strömvik concluded that "the political will to cooperate has periodically increased when EU members have disagreed with American strategies on international security management" (Strömvik, 2005). So, we may state when analysing the CSDP that realism provides the most convincing theory. Ideas and institutions indeed played a role in the development of the CSDP but they are set against the state, and it is the state that maintains the military capabilities and the political interests for which such capabilities are required (Fiott, 2013).

Nowadays, we may state that the Common Foreign and Security policy, the formation of which began in the late twentieth century, is one of the new areas for dynamic integration within the European Union. The EU Common Security and Defence policy is part of the EU Common Foreign and Security Policy (CFSP), which until 2009 was the second 'pillar' of the EU, institutionalised in 1993. Under the Lisbon Treaty, the CFSP actually consists of two parts: a Common Foreign Policy and its autonomous component - the European Security and Defence Policy (ESDP), later named the Common Security and Defence Policy (CSDP). As stated in the Treaty on European Union, its objective is to "ensure the Union's capacity for operational actions based on civil and military means" (p. 1, Art. 42). In the future, the ESDP "includes the progressive framing of a common defence policy of the Union" (p. 2, Art. 42) (Principles of EU Law: normative materials (amended by the Treaty of Lisbon, 2010)).

The European Security and Defence Policy, officially launched at the EU summit in Cologne in June 1999, was a logical continuation of the implementation of the Common Foreign and Security Policy of the EU. The impetus for the deepening of cooperation of the member states in the field of security and defence was the crisis in Kosovo, which is why, since late 1998, EU member states started to assemble their own intensive integration and political efforts in the field of security and defence. So, at the session of the European Council in Cologne, the heads of member states and the heads of governments embarked on building the European Security and Defence Policy, based on the following objectives: strengthening the capacity of the EU in the areas of peacekeeping, forming the capacity of the EU in the military field for conflict prevention and crisis management within the "Petersberg tasks," as well as assigning the necessary tasks of the WEU to the 'second pillar' of the EU (foreign jurisdiction and security), the prevention of conflicts and strengthening of international security in accordance with the principles of the UN Charter (Fesenko, 2010). This, in turn, required improving the military capabilities of the member states. Also, EU member states tried to intensify this process within the Western 
European Union (WEU). But the result of the pan-European debate was understanding the feasibility of accumulating the efforts and opportunities within the EU policy. For the WEU it meant its actual structural and functional dissolution in the CSDP.

At the summit of the European Council in Nice in December 2000, the heads of member states and the heads of governments completed the formation of the CSDP structures responsible for security and defence, the concept of which was developed at the Cologne summit. Decisions are usually made by the EU Council. The structural unit which is responsible for this is the General Affairs \& External Relations Council, whose membership is made up of foreign ministers (Shatun, 2014).

The European Security Strategy, adopted on 12 December 2003, defined the new global challenges the international community was facing, and therefore the main threats to European security. These primarily include: terrorism, the proliferation of weapons of mass destruction, regional conflicts and organised crime. In relation to certain threats, specific goals were outlined in which Europe should strive to protect its own security. In responding to these threats it should establish mechanisms for prevention and response, including in the sphere of active crisis management and international cooperation. It should build security in the EU neighbourhood, respond to threatening tendencies in its neighbourhood, prevent and avoid conflicts and crises, create an international order based on effective multilateral cooperation, and actively cooperate with other influential players in the international arena, especially with influential international organisations (Snihyr, 2010).

The Strategy also calls for intensification of EU foreign policy efforts by improving the potential of opportunities and improving coordination. The document stresses the need to strengthen international institutions and international law, with special emphasis on the preventive character of all EU instruments, and at the same time the use of military force as a last means for conflict prevention and crisis management is not excluded.

With the entry into force of the Lisbon Treaty on 1 December 2009, which made appropriate changes to the founding treaties of the EU, the post of President of the European Union was introduced. He heads the European Council and represents the EU in the sphere of common foreign and security policy, without overlapping the powers of the High Representative of the Union for Foreign Affairs and Security Policy. To implement the adopted decisions, a number of executive bodies were set up: the Office of the High Representative of the Union for Foreign Affairs and Security Policy, Political and Security Committee, Military Committee and EU Military Staff. The key provision of the Lisbon Treaty is the mutual defence clause, which obliges member states to provide assistance and support in cases where "a Member State is the victim of armed aggression on its territory." This clause is very similar to Article V of the Washington Treaty. It is a commitment to collective defence in case of a military attack against any of the member states, as well as outlining the provisions for the mutual defence commitment of EU members in case of a terrorist attack, natural or man-made disasters (Treaty of Lisbon, 2007).

After the reform of the Lisbon Treaty the option for a categorical statement that the European Union carries out its activities in the international arena only in two directions - the Community's foreign policy and the CSDP was removed. The main issues of the first direction are the issues of international cooperation in the economic and social 
spheres, including science, culture and environmental protection. And the main issues of the CSDP, respectively, include any issues of international relations that do not include the foreign policy competence of the EU. They include, in particular, issues of international peace and security (Margaras, 2010).

The competencies of the EU in CSDP are correlated by the obligation of the member states to "actively and unreservedly support the CSDP in a spirit of loyalty and mutual solidarity and comply with the Union's action in this area." The member states "shall work together to enhance and develop their mutual political solidarity." They "shall refrain from any action which is contrary to the interests of the Union or likely to impair its effectiveness as a cohesive force in international relations" (p. 3. Art. 24, Treaty of Lisbon).

In implementing this policy, a problematic issue is the distribution of powers between the EU and NATO, of which the majority of EU member states are also members. The decisions of the jubilee NATO Washington Summit in 1999 expressed support for "the EU's determination to be capable of independent actions, which involve decisionmaking and approval of military actions when NATO itself is not involved" (Sheludchenkova, 2011).

Taking into consideration these specific international obligations of the EU member states (neutrality, NATO membership) graded participation in the policy is provided for. NATO's role in implementing the ESDP is particularly highlighted. For groups of member states seeking to follow the path of cooperation in specific areas of ESDP deeper than others are willing, the opportunity is given to do so using the resources of the EU but without going beyond its institutional system. And some states may carry out peacekeeping missions by Council decision and at the same time represent the interests of the whole EU.

\section{The Ukrainian crisis 2013-2015 as the biggest challenge to European security since the end of the Cold War}

The Ukrainian crisis 2013-2015, connected with the illegal, armed seizure of the territory of Ukraine (Crimea) and its annexation to Russia, and the later hybrid Russian aggression against Ukraine in the Donetsk and Lugansk regions affected fundamental issues of European and global security.

Herman Van Rompuy said that since the end of the Cold War the Ukrainian crisis is the biggest threat to European security. This is because the Russian aggression against Ukraine, the occupation of Crimea and events in eastern Ukraine showed that the system of European and global security was largely helpless and ineffective, putting into question the possibility of sustainable development on the continent.

Russia's actions against Ukraine undermined regional stability in countries from the Baltic to the Black Sea and the Caspian basin, creating a challenge for NATO as a key element of the European security and putting into question the fate of the entire European project and the idea of a united Europe.

After the Russian invasion in Ukraine, the fears and scepticism mainly of the countries of Central and Eastern Europe have found justification. Consequently, they requested an 
increase in the protection of the Eastern flank of the EU and, most importantly, NATO's presence has significantly increased there. This threat is especially real for Lithuania, Latvia and Estonia, which hold a special place in the geopolitical views of Moscow. It treats them as 'historical Russian territory' in the Baltic region. In addition, the Kremlin opposes their membership of NATO and the EU, as they set an example for European and Euro-Atlantic integration for the former USSR republics.

The Ukrainian crisis and the recent refugee crisis are big challenges for the European Union, which recently has heard a lot of criticism of a lack of efficiency, lack of democracy, lack of solidarity and ultimately, according to J. Juncker, even a lack of Europe and a lack of Union. These challenges require the rethinking of many aspects of the EU. Where are Europe's borders? What are the European values? How are they to be protected? What should the instruments of European security be?

The system of European and global security, as we can see, is not able to cope with the crisis, and therefore, must be rethought. The principles of the inviolability of borders, sovereignty, territorial integrity, loyalty to international obligations, of resolving conflicts through negotiation, not confrontation - all these principles which have been relevant to Europe for more than 70 years, today are grossly violated.

The EU faced the need to change certain principles of its operation, particularly the principles of decision-making, their pace and level of solidarity, that do not meet the needs of current realities.

The obvious presence of Russian troops in Eastern Ukraine at the end of August 2014 finally made the EU act more forcefully. This mostly took the form of strengthened sanctions against Russia. The EU sanctions announced on 12 September 2014 targeted Russia's state finances, energy and arms sectors. These are sectors managed by the powerful elite around President Vladimir Putin. Even during the consultations on the sanctions there were countries which didn't support them, or wanted them to be short term. It also should be noted that the EU imposed sanctions only after the USA did so.

The Ukraine crisis should be regarded not as a sudden European failure, but rather as a wake-up call for the necessity to finally start a deliberate debate on EU security, defence and strategic recalibration. It is important to take into account that neither NATO without the EU, nor the EU without NATO is capable of effectively managing the new hybrid threats. Europeans should not view EU and NATO security solutions as mutually exclusive. Each separate EU and NATO member state cannot react effectively to these security challenges, and increasing cooperation between the EU and NATO is necessary. That would provide the possibility of using the advantage of a union, instead of being targeted individually by opponents. The EU can be a strong support for NATO on such security issues as cyber defence, information space and border security, taking into account the current challenges on the EU's eastern borders (Pabriks, Kudors, 2015).

\section{The security of the Baltic states: CSDP and/or NATO?}

The Baltic countries, being members of both NATO and the EU, and therefore part of the Common Security and Defence Policy, yet believe that the United States is the main guarantor of their national security. One reason is the perception of Russia as the main 
source of instability. Another one is the lack of confidence in the ability of the CSDP to confront modern threats. Though these states have become full members of the European Union and its policies, their confidence in the ability of the EU to create a strong defence policy is low. The military power of the EU without US military support is considered almost hopeless for them. However, they see their role in the coordination of cooperation between NATO and the EU in the security and defence sphere. Estonia, Latvia and Lithuania want to be "the NATO forces in the European Security and Defence Policy" (Tromer, 2003).

The Baltic countries identified a list of subjects that directly affect their national security. These are the USA, NATO and the EU and other partner countries, including the Scandinavian countries. They also distinguish between military and economic security; NATO is the main instrument to provide the first, and the EU - the other.

The Baltic states know that their military capabilities will not hold up against Russia's aggression, as the NATO response might arrive too late. Combined, all Baltic defence forces comprise around 22,000 troops, 448 heavy artillery pieces and no tanks or warplanes. At the same time, the total Russian conventional capability consists of 845,000 troops, 5,436 heavy artillery pieces, 2,550 tanks and 1,389 warplanes (Nikers, 2015).

The position of Estonia, Latvia and Lithuania towards the CSDP is as follows: none of the Baltic states sought to give the EU stringent regulatory mechanisms in the sphere of security and defence, but wanted to limit its competences to the issues of crisis management and 'soft security.' The unclear description of the EU force mission (as it is set out in the Petersberg Declaration of 1992 and enshrined in the Treaty of Amsterdam in 1997, and later in other EU documents) was entirely acceptable to the Baltic states. Their participation in the ESDP is more symbolic, because they always state that they may limit their participation in European Security and Defence Policy if it is contrary to, or interferes with their obligations to NATO. For the Baltic states the main purpose of their security and defence policy is to maintain strong transatlantic ties. However, this does not mean that they are afraid to be active participants in the European Security and Defence Policy; on the contrary, they are striving to create it, and not just joining an already established policy. The emphasis is on their participation in the decision-making process and the reception of new opportunities for realisation of their national interests in the security and defence sphere.

For the Baltic states, two components of the CSDP are important: the European Defence Agency (EDA) and the battle groups. The decision to establish the European Defence Agency stressed the need to harmonise the efforts of member states in the development of defence capabilities; to coordinate the production and purchase of weapons; and the implementation of policies to strengthen the defence industry of the EU.

While the interest in the EDA is significant, the issue of the creation of battle groups is being considered in the Baltic states. The concept of the creation of battle groups has been proposed in order to solve one of the current problems, namely the lack of opportunities to deploy smaller rapid response groups.

Estonia, Latvia and Lithuania believe that the new structure (CSDP) is currently under development, and for now is unable to contribute significantly to the security of the Baltic states. That is why they still see NATO as the main guarantor of their security, sovereignty and territorial integrity. 
The Baltic states are working simultaneously along several lines to add more to the CSDP: the creation of a new mobile joint battalion, an increase in the budgetary resources allocated for civilian assistance, and participation in battle groups are just some of the initial signs. The limited military capabilities are also compensated with greater interest for ENP target countries assistance, where the Baltic states can play an important role in conflict prevention and the construction of a sustainable peace. Nevertheless, it is still obvious that, being so small, the Baltic states cannot be represented in every CSDP mission and activity. Thus, they will continue to focus on developing niche capabilities like mine-clearing, medical support and border-management. Furthermore, the Baltic states understandably tend to concentrate their attention on the geographical areas where they have the most experience and requisite competence, i.e. primarily the former Soviet Union and other previously communist-ruled countries. Baltic participation in the CSDP could accelerate and be more meaningful if the old member states better appreciated that the Baltic states do not have the same experience of 50 years of 'peace and prosperity' as Western Europe, but still need time to overcome the traditional threats from Russia. While the Baltic states try more and more to understand and follow CSDP values, the next step for fruitful cooperation could be that old member states start to reflect more Baltic interests in the next European Security Strategy, and thus a common security strategy will become common also in practice (Kasekamp, Veebel, 2007).

Nowadays, the Baltic states, in close cooperation with the US and NATO, have to step up their efforts to counter the threats from the Russian Federation. In particular, this was one of the leading themes of the NATO summit in Wales in September 2014, where it was decided to strengthen the military presence of the US and NATO in Lithuania, Latvia, Estonia and Poland (deployment in each of these countries of tactical groups on a rotation basis of a total of up to 1,000 soldiers) and enhance the measures of operational and combat training of NATO Allied Command Transformation (ACT) in the region.

Particular fears that Russia will use the practice of 'hybrid' war in their countries are present in the societies of Latvia and Estonia. The main reason is the large number of ethnic Russians, who could form the social basis for separatist movements.

A potential 'people's republic' in Estonia is the Ida-Virumaa district, with its administrative centre in Narva, where ethnic Russians make up more than $80 \%$ of the population. In Latvia, this is the historical region of Latgale, where the rate of ethnic Russians is $35-40 \%$. An alarm bell for the official authorities of Latvia is the activation of the local left-wing party "Latvian Russian Union," the only political party which recognised the annexation of the Crimea.

The sharp increase in the number of violations of the Baltic states' air borders by Russian planes is of particular concern. In this regard, the mission units of NATO airspace guard have increased the number of fighter planes in Lithuania (to eight units) and four F-16 fighters of the Royal Air Forces of Denmark have been sent to Estonia. Also, an additional four fighter planes have been stationed at the military air base in the Polish town of Malbork. The Baltic states also feel insufficiently protected within their territorial waters. The reason for this is the story of a Russian submarine that recently 'got lost' in the territorial waters of Sweden.

The 'appearance' of Russian weapons in the Baltic region and the cautious position of Western leaders drove Poland and the Baltic states to take care of strengthening their 
security on their own, using the resource base of NATO. That is why the government of Latvia plans to increase defence funding to $2 \%$ of GDP by 2020, as agreed at the last NATO summit. Particular attention is being paid to air defence, on which 140 million euros will be spent in the coming years.

In March 2014, the Lithuanian parliament passed a decision to increase defence spending up to 2\% of GDP (according to NATO standards) and those in October 2014 it approved a package of amendments to major legislation in the field of security and defence, in particular, the laws "On the rules and conditions of the usage of Military Forces," "On Protection of Lithuania from armed attack" and "On the Union of Riflemen of Lithuania." Since 1 October 2014 around 150 American soldiers have begun to perform their duties in Lithuania. Heavy armoured equipment was sent to Lithuania (including eight "Stryker" armoured vehicles and eight "Bradley" armoured infantry carriers). A group of German soldiers with military equipment is also based there. Similar units are located in other Baltic states (Independent Analytical Center for Geopolitical Studies, 2014).

The Baltic region has also become the venue for large-scale military training involving NATO forces. In November 2014, Lithuania hosted the international NATO military training "Iron Sword - 2014," which involved more than 300 units of military equipment for various purposes and 2,500 soldiers from 9 NATO countries (the United States, Germany, Canada, UK, Czech Republic, Estonia, Lithuania, Luxembourg and Hungary).

It seems, though, that such NATO acts are still not enough for the Baltic states to feel completely safe. However, it appears NATO is not going to lose the strategically important foothold in the Baltic states, and defensive measures there will only intensify.

Cooperation among the Baltic states in the security sphere is very important, too. For example, in November 2014 the Commanders-in-chief of the Armed Forces of Latvia, Lithuania and Estonia met to discuss the coordination of military cooperation of the three countries in the light of the decisions of the Wales Summit. Special attention at the meeting was paid to deepening trilateral cooperation within the projects of development and support of the Navy squadron of the Baltic states BALTRON, air defence and airspace BALTNET, as well as the Baltic Battalion (in 2016 it was added to the NATO Response Forces).

One more aspect of the Baltic states' security is the energy issue. The authorities of the Baltic states are trying to reduce their energy dependence on Russia. To make this possible, in October 2014 the construction of a floating terminal for receiving and regasification of liquefied natural gas was completed in the Lithuanian city of Klaipeda. Since the beginning of work on this terminal (scheduled for January 2015) Lithuania has not only removed the Russian gas monopoly, but also obtained direct access to world gas markets. In future, the terminal will provide gas to other Baltic states.

In turn, the government of Estonia is trying to regain control of the national gas distribution network. For this, it plans to buy a controlling stake in the operator of that network - the company EG Vorguteenus, which actually belongs to the Russian "Gazprom."

Much attention is paid by the governments of the Baltic states to the issues of combating Russian influence in the IT sector as this is one of the main instruments of 'hybrid war.' Therefore, in Lithuania the broadcasting of Russian TV channels (RTR, ORT, NTV) has been stopped and the activities of pro-Russian Lithuanian media (weekly newspaper 
Lithuanian courier, Overview, Express week and TV channel Baltic channel - a subsidiary of ORT in the Baltic states) are more tightly controlled.

It should be noted that Lithuania practically abandoned the development of relations with Russia in the cultural sphere. For example, the Ministry of Culture of Lithuania did not sign the cooperation program with Russia in this sphere for 2014-2015, and the plan for joint projects with the Russian Federal Agency "Rossotrudnychestvo" which openly adheres to the neo-imperial policy of the Russian Federation. According to the State Security Department of Lithuania, "Rossotrudnychestvo" attracts young Russian-speaking Lithuanians to study in Russia, popularises training in various paramilitary camps (with anti-Lithuanian indoctrination). These facts are the subject of a special investigation of the General Prosecutor's Office and the State Security Department of Lithuania (Independent Analytical Center for Geopolitical Studies, 2014).

Control over the activities of the Russian media in Latvia has also increased. For example, the Baltic channel had a fine imposed by the Latvian National Council for the biased coverage of events in Ukraine and inciting ethnic hatred. In addition, there is a solution to limit the retransmission of the RTR Russia channel on Latvian territory.

In order to prevent the strengthening of the Russian influence in Latvia, the entry of Russian citizens to the country is limited. In late October 2014, the Latvian Parliament adopted amendments to the Immigration Act, which provides for the suspension of issuing of temporary residency cards for Russian citizens and their purchasing property on Latvian territory.

It is estimated that all the newly listed measures implemented by the Baltic states will increase counter aggression from the Russian Federation, including the tactics of 'hybrid warfare' and methods of 'soft power.' Their membership of NATO and the EU are the most important factors in ensuring the security of Lithuania, Latvia and Estonia, and this may mainly curb Russian military expansion in that region. As former European Commission President Mr. Barroso said, "if the Baltic states hadn't joined NATO and the EU, they would have been swallowed by Russia."

\section{Conclusions}

The European Union has made substantial progress in implementing the EU Common Security and Defence Policy. But it is clear that the formation and development of the Common Security and Defence policy requires much greater political efforts and resources. Also it is necessary to achieve consensus on the priorities of foreign policy of the EU, within which the strategic objectives of CSDP are formed. The institutional and administrative system of the CSDP also requires improving and strengthening.

The aggression of Russia against Ukraine is a litmus test for the CSDP concerning the national security of Estonia, Latvia and Lithuania. If the CSDP seeks to ensure the security of the Baltic states in particular, it is necessary first of all to define the threat and also to recognise its failures, in particular the fact that the EU's desire to consider the Russian Federation as a democratic partner failed. Though the Baltic states want to become 'full-scale' members of the European Union and its policies, their confidence in the ability of the EU to create a strong defence policy is low. The military power of the 
EU without US military support is considered almost hopeless for them. However, they see their role in the coordination of cooperation between NATO and the EU in the sphere of security and defence.

The Baltic states, which are now in the most vulnerable in terms of possible Russian aggression among other EU member states, are showing their willingness to defend themselves, but it is obvious that they are not able to do that without the NATO and EU instruments. Since the beginning of the Ukrainian crisis in 2014, EU leaders have intensified discussions and consultations on the adequate response to the challenges. The main task was to show the unity of the EU, and that took the form of increased sanctions against Russia. Following the decision taken at the Newport NATO summit in 2014, the scale of exercises with the participation of NATO troops has also increased in the Baltic states. NATO has created a rapid reaction force of 4,000 troops that could arrive in the Baltic states at short notice. The Baltic states should also strengthen military cooperation among themselves on the basis of the existing cooperation (for example, BALTBAT and BALTNET) and increase their defence spending. These three elements should become the core of a Baltic states' defence system which may guarantee their security.

\section{Bibliography}

Baun M., Marek D. (2013), The New Member States and the European Union, Foreign Policy and Europeanization, Routledge.

Biehl H., Giegerich B., Jonas A. (2013), Strategic Cultures in Europe: Security and Defence Policies Across the Continent, Springer Science \& Business Media.

Dahl A.-S., Järvenpää P. (2013), Northern Security and Global Politics, Nordic-Baltic Strategic Influence in a Post-unipolar World, Routledge.

Etzioni A. (2001), Political Unification Revisited. On Building Supranational Communities, Lanham, MD: Lexington.

Fesenko N. (2010) The formation and development of the European Security and Defence Policy, no. 2(38).2010, http://www.kbuapa.kharkov.ua/e-book/apdu/2010-2/doc/4/01.pdf.

Fiott D. (2013), The Common Security and Defence Policy and IR Theory, http://www.e-ir. info/2013/08/20/the-common-security-and-defence-policy-and-ir-theory/.

Grigas A. (2013), The Politics of Energy and Memory Between the Baltic States and Russia, Ashgate.

Grigas A., Kasekamp A., Maslauskaite K., Zorgenfreija L. (2013), The Baltic States in the EU: yesterday, today and tomorrow, http://www.institutdelors.eu/media/balticstateseu-grigaskasekampmaslauskaitezorgenfreija-ne-jdi-july13.pdf?pdf $=$ ok.

Herd G. P., Moroney J. D. P. (2013), Security Dynamics in the Former Soviet Bloc, Routledge.

Howorth J. (2014), Security and Defence Policy in the European Union, Palgrave Macmillan.

Jacobson B. (ed.) (2010), The European Union and the Baltic States: Changing Forms of Governance, Routledge.

Kasekamp A., Veebel V. (2007), Overcoming doubts: The Baltic states and the European Security and Defence, "The Estonian Foreign Policy Yearbook 2007", http://www.isn.ethz.ch/DigitalLibrary/Publications/Detail/?lang=en\&id=56889.

King G. J., McNabb D. E. (2014), Nation-Building in the Baltic States: Transforming Governance, Social Welfare, and Security in Northern Europe, CRC Press.

Koutrakos, P. (2013), The EU Common Security and Defence Policy, Oxford University Press, Oxford. 
Kramer M. (2002), NATO, the Baltic States and Russia: A Framework for Sustainable Enlargement, "International Affairs" (Royal Institute of International Affairs), vol. 78, no. 4 (Oct., 2002), pp. 731-756.

Larivé M. H. A. (2014), Debating European Security and Defense Policy. Understanding the Complexity, Ashgate, Hampshire.

Margaras V. (2010), Common Security and Defence Policy and the Lisbon Treaty Fudge: No common strategic culture, no major progress, EPIN Papers Working Paper, no. 28, June.

Medley R. (1999), Europe's Next Big Idea. Strategy and Economics Point to a European Military, "Foreign Affairs" no. 5 (78), pp. 18-22.

Merlingen M. (2012), EU Security Policy: What It Is, How It Works, Why It Matters, Lynne Rienner, Boulder, CO.

Nikers O. (2015), Latvia in Focus: National security options for the Baltic states, "New Eastern Europe", 07.09.2015, http://www.neweasterneurope.eu/articles-and-commentary/1710-latvia-infocus-national-security-options-for-the-baltic-states.

Ojanen H. (2002), Theories at a Loss. EU-NATO Fusion and the 'Low-Politicization of Security and Defence in European Integration, UPI Working Papers 35, The Finnish Institute of International Affairs, Helsinki.

Pabriks A., Kudors A. (2015), The War in Ukraine: Lessons for Europe, The Centre for East European Policy Studies University of Latvia Press Rīga.

Principles of the EU Law: normative materials (amended by the Treaty of Lisbon), Kharkiv, 392 pp.

Shatun V. (2014), Defence and security policy of the European Union: formation and evolution, "Scientific works. Politology", no. 218, vol. 230, 2014,http://irbis-nbuv.gov.ua/cgi-bin/irbis_nbuv/cgiirbis_64.exe?C21COM=2\&I21DBN=UJRN\&P21DBN=UJRN\&IMAGE_FILE_ 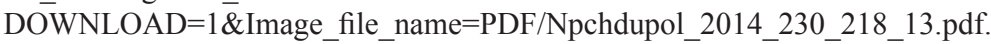

Sheludchenkova A. (2011), Common Security and Defence Policy in the structure of the European Union, "Actual problems of the state and law", no. 54, http://irbis-nbuv.gov.ua/cgi-bin/irbis_nbuv/cgiirbis_64.exe?C21COM=2\&I21DBN=UJRN\&P21DBN=UJRN\&IMAGE_FILE_ DOWNLOAD=1\&Image_file_name=PDF/apdp_2011_60_54.pdf.

Snihyr O. (2010), European Security and Defence Policy: strategic aspects of cooperation between Ukraine and the EU determination of areas and format, http://old.niss.gov.ua/Monitor/November/2.htm.

Strang J. (2015), Nordic Cooperation: A European region in transition, Routledge.

Strömvik M. (2005), To Act as Union. Explaining the Development of the EU's Collective Foreign Policy, Lund Political Studies 142, Lund University: Department of Political Science.

The Baltic Countries' Experience in Counteracting the Aggression of the Russian Federation, Borysfen Intel, 2014, http://bintel.com.ua/en/article/print/opyt-baltii/.

Treaty of Lisbon (2007), Official Journal of the European Union, vol. 50, 17.12.2007.

Tromer E. (2003), Baltic perspectives on the European Security and Defence Policy, http://books.sipri. org/files/books/SIPRI06BaHeSu/SIPRI06BaHeSu23.pdf.

\section{Bezpieczeństwo państw baltyckich: skuteczność Wspólnej Polityki Bezpieczeństwa i Oobrony i wpływu „kryzysu ukraińskiego"}

\section{Streszczenie}

W artykule przeanalizowane zostały przyczyny i rozwój unijnej Wspólnej Polityki Bezpieczeństwa i Obrony (WPBiO), jej zalety i wady ujawnione w procesie tworzenia i wdrażania. Szczegółowo przedstawiono transformację WPBiO zgodnie z Traktatem Lizbońskim oraz perspektywy jej działania 
w Europie. Szczególną uwagę zwrócono na kwestie poprawy efektywności funkcjonowania WPBiO w kontekście nowych zagrożeń dla bezpieczeństwa regionalnego i globalnego. Dodatkowo przeanalizowano miejsce i rolę państw bałtyckich w WPBiO. Do podstawowych zagrożeń i wyzwań bezpieczeństwa przed jakimi stoją zaliczane są przede wszystkim ewentualna agresja ze strony Rosji, która opiera się na idei ochrony ludności rosyjskojęzycznej w państwach bałtyckich oraz ustanowieniu „,równowagi geopolitycznej poprzez ich powrót do rosyjskiej strefy wpływów".

Słowa kluczowe: Wspólna Polityka Bezpieczeństwa i Obrony (WPBiO), UE, bezpieczeństwo europejskie, państwa bałtyckie, Ukraina, Rosja 